\title{
The impact of banking concentration on firm leverage in emerging markets
}

\author{
ABSTRACT \\ Purpose \\ The purpose of this paper is to explore the impact of banking concentration on firm leverage \\ in 21 major emerging countries from different geographical regions, controlling for firm \\ determinant and macroeconomic determinant of firm leverage.
}

\section{Design/methodology/approach}

This study is based on a relatively large sample of 5,779 enterprises with total 48,280 numbers of observations over the period from 2006 to 2013 and the regression model is performed by applying two-step system general method of moment estimator methodology.

\section{Findings}

This study finds a positive and significant relationship between banking concentration and firm leverage. Therefore, the overall results follow the information-based theory which indicates lower firms financing obstacles as banks are more concentrated.

\section{Research limitations/implications}

Bank-level data of all the countries to measure banking concentration is until 2013, which restrict the empirical analysis until 2013. Also, the study conducts the analysis.

\section{Practical implications}

The study enables policymakers, society, and academics to have better understanding on the beneficial effects of alternative banking market structure on firms'access to credit and therefore, in determining the level of firm leverage in emerging countries.

\section{Originality/value}

The study represents one of the limited available empirical researches to examine the beneficial effect of alternative banking market structures of firm leverage in emerging countries.

Keyword: Emerging markets; Banking concentration; Firm leverage; Market power and information-based theory 